\title{
Effect of Far-infrared Radiation for Dying Citnus By-products and Their Radical Scavenging Activities and Protective Effects Against $\mathrm{H}_{2} \mathrm{O}_{2}$-induced DNA Damage
}

\author{
Mahinda Senevirathne ${ }^{1}$, You-Jin Jeon ${ }^{2}$, Jin-Hwan $\mathrm{Ha}^{1}$, and Soo-Hyun $\mathrm{Kim}^{1 \dagger}$ \\ ${ }^{1}$ Department of Food Bioengineering and ${ }^{2}$ Faculty of Applied Marine Science, \\ Cheju National University, Jeju 690-756, Korea
}

\begin{abstract}
Efficiency of a far-infrared radiation (FIR) dryer for drying of citrus by-products (CBPs) was evaluated through their antioxidant activities. The CBPs dried through FIR were enzymatically digested by six carbohydrases (AMG, Celluclast, Pectinase, Temamyl, Ultraflo and Viscozyme) to prepare digests for evaluation of the activities. The total polyphenolic and total flavonoid contents of the digests were detemined by colonimetric assays. The AMG digest was selected for the further experiments. The antioxidant potential of the digests were evaluated by DPPH, superoxide, hydroxyl and alkyl radical scavenging activities, $\mathrm{H}_{2} \mathrm{O}_{2}$ scavenging activity, metal chelating, lipid peroxidation inhibition and the reduction of DNA damage. The AMG digest from CBPs dried through FIR at $50^{\circ} \mathrm{C}$ showed strong antioxidant activities in DPPH, superoxide, hydrogen peroxide, alkyl and metal chelating assays while all the digests showed strong lipid peroxidation activities. Further, enzymatic digests showed remarkable inhibitory activities against $\mathrm{H}_{2} \mathrm{O}_{2}$-induced DNA damage. Hence, the data obtained using different in vitro models clearly established the antioxidant potential of enzymatic digests from CBPs dried through FIR. Furthemore, they can be used as a source of natural antioxidants; hence, far-infrared radiation drying is a viable method for transforming wet CBPs into a dried form without destroying the bioactive components.
\end{abstract}

Key words: antioxidant activity, citrus by-products, DNA damage, enzymatic digests, far-infrared radiation drying

\section{INTRODUCTION}

Antioxidants may act in various ways such as scavenging free radicals, decomposing the peroxides and chelating the metal ions. The antioxidant potential of a compound can be broadly divided into two classes, depending on the nature of the reactions. Those are hydrogen atom transfer and electron transfer based reactions. Hydrogen atom transfer methods evaluate the ability of an antioxidant compound to quench free radicals by hydrogen donation while electron transfer methods measure the ability of an antioxidant to transfer one electron to reduce radicals, metals or carbonyl groups (1). The electron transfer and hydrogen atom transfer reactions may occur in parallel, and the mechanism dominating in a given system will be determined by antioxidant structure, properties, solubility, partition coefficient, and system solvent (2).

Fruits and vegetables contain other antioxidant compounds in addition to vitamins $\mathrm{C}, \mathrm{E}$, and carotenoids, which highly contribute to their antioxidant activity as proven by many researchers $(3,4)$. The polyphenolic compounds, that are secondary metabolites of plants, may also act as antioxidants. The flavonoids are phenolic compounds abundantly found in citrus peels and, are believed to exhibit a variety of biological activities. They have a wide range of activities, such as antioxidant, antibacterial, cell-proliferation-inhibiting and apoptosis-inducing activities (5-7). Moreover, some findings indicate that flavonoids possess various clinical properties, such as antiatherosclerotic, antiinflammatory, antitumour, antithrombogenic, and antiviral effects $(5,6)$.

Numerous bioactive compounds are present in plants, fruits or in their processing by-products, and they can be extracted by various extraction methods. In this study, the bioactive compounds in citrus by-products were obtained by the enzymatic digestion. The enzymes work primarily by macerating the tissues and breaking down the cell walls as well as complex interior storage materials to release the bioactive compounds. Further, the enzymatic digestion process possesses a number of advantages and characteristic features such as higher extraction efficacy, water solubility, minimized environmental pollution and relatively less expensiveness compared to the conventional extraction methods.

Large amounts of by-products are formed every year

${ }^{\dagger}$ Corresponding author. E-mail: kshyun@cheju.ac.kr

Phone: +82-64-754-3614, Fax: +82-64-755-3601 
by citrus juice processing plants and they may be an excellent source for a number of phytochemicals, which may show numerous biological activities. However, those by-products should be converted into a dried form before being used as they may deteriorate rapidly. Far-infrared radiation (FIR) drying was applied to convert the wet citrus by-products into a dried form in order to increase the efficacy in the drying process. Many researchers have used FIR or other irradiation processes to evaluate the activities of citrus peel or other agricultural materials (8-12). FIR drying provides many advantages over conventional drying methods. When FIR is used to dry some material, the radiation collides with the surfaces of the exposed material and penetrates to create internal heating with molecular vibration of the material while FIR energy is converted into heat (13). The depth of penetration depends on the composition and structure of the material and also on the wavelengths of FIR. It has been reported that the drying rate of the FIR drying process is faster than conventional hot-air drying, and increases with increased power supplied to the far infrared emitter (14). The drying of citrus byproducts by FIR may be an effective method to liberate antioxidative polyphenolic compounds which exist in a covalently bound form with polymers $(15,16)$. The aim of this study was to evaluate the effectiveness of far-infrared radiation drying and the survival of antioxidant activity.

\section{MATERIALS AND METHODS}

\section{Materials}

1,1-diphenyl-2-picrylhydrazyl (DPPH), 5,5-dimethyl1-pyrrolin N-oxide (DMPO), 2,2-azobis (2-amidinopropane) hydrochloride (AAPH) and 2,2'-azino-bis (3-ethylbenzo thiazoline-6-sulfonic acid (ABTS) were purchased from Sigma Chemical Co. (St. Louis, USA). Viscozyme L (a multi-enzyme complex containing wide range of carbohydrases, including arabinase, cellulase, beta-glucanase, hemicellulase and xylanase), Celluclast 1.5L FG (catalyzing the breakdown of cellulose into glucose, cellobiose and higher glucose polymers), AMG 300L (an exol, 4-alpha-d-glucosidase), Termamyl 120L (a heat stable alpha amylase), Ultraflo L (a heat stable multi-active beta-glucanase) and Pectinex were purchased from Novo Co. (Novozyme Nordisk, Bagsvaed, Denmark). All other chemicals used were analytical grade supplied by Fluka or Sigma Co.

\section{FIR drying of citnus by-products}

CBPs were collected from a citrus juice processing factory in Jeju Island, Korea from January to March,
2007 and they were stored at $-50^{\circ} \mathrm{C}$ until drying by FIR (Model TOURI-Q, Korea). CBPs were dried by FIR drier at different temperatures $\left(40,50,60,70\right.$, and $\left.80^{\circ} \mathrm{C}\right)$. Then, the dried CBPs were pulverized into a fine powder using a grinder (MF 10 basic mill, GMBH \& Co. Staufen, Germany) and sieved through a $300 \mathrm{~mm}$ standard testing sieve.

\section{Preparation of enzymatic digests}

One gram of FIR-dried CBPs was mixed with 100 $\mathrm{mL}$ of distilled water. The optimum $\mathrm{pHs}$ of all reaction mixtures were adjusted with $1 \mathrm{M} \mathrm{HCl} / \mathrm{NaOH}$ as described by Heo et al. (17). Thereafter, enzymatic digestion was performed for $24 \mathrm{hrs}$ to reach an optimum degree of extraction. Resultant mixtures were inactivated by keeping them in a water bath at $100^{\circ} \mathrm{C}$ for $10 \mathrm{~min}$ and filtering. Finally, each digest was adjusted to $\mathrm{pH}$ 7 with $1 \mathrm{M} \mathrm{HCl} / \mathrm{NaOH}$.

\section{Detemination of total phenolic content}

The total polyphenolic content was determined according to the method described by Chandler and Dodds (18). One millilitre of the enzymatic digest/water extract obtained from the dried CBPs was mixed in a test tube containing $1 \mathrm{~mL}$ of $95 \%$ ethanol, $5 \mathrm{~mL}$ of distilled water and $0.5 \mathrm{~mL}$ of $50 \%$ Folin-Ciocalteu reagent. The resultant mixture was allowed to react for $5 \mathrm{~min}$ and 1 $\mathrm{mL}$ of $5 \% \mathrm{Na}_{2} \mathrm{CO}_{3}$ was added. It was mixed thoroughly and placed in the dark for $1 \mathrm{hr}$ and absorbance was recorded at $725 \mathrm{~nm}$ in the UV-VIS spectrophotometer (Opron 3000 Hansan Tech. Co., Ltd., Korea). A gallic acid standard curve was obtained for the calculation of the polyphenolic content.

\section{Detemination of total flavonoid content}

The total flavonoid content of the enzymatic digest/ water extract obtained from the dried CBPs was determined by the method described by Zhuang et al. (19) with slight modifications. A $0.5 \mathrm{~mL}$ aliquot of the digest/extract was mixed with $2 \mathrm{~mL}$ of distilled water and subsequently with $0.15 \mathrm{~mL}$ of a $5 \% \mathrm{NaNO}_{2}$ solution. After $6 \mathrm{~min}, 0.15 \mathrm{~mL}$ of a $10 \% \mathrm{AlCl}_{3}$ solution was added and allowed to stand an additional 6 min, thereafter 2 $\mathrm{mL}$ of $4 \% \mathrm{NaOH}$ solution was added to the mixture. Immediately, distilled water was added to bring the final volume to $5 \mathrm{~mL}$. Then the mixture was properly mixed and allowed to stand for $15 \mathrm{~min}$. Absorbance of the mixture was taken at $510 \mathrm{~nm}$. Rutin was used as standard for the quantification of the total flavonoid content.

\section{DPPH radical scavenging assay}

This assay is based on the scavenging ability of stable 1,1-diphenyl-2-picrylhdrazyl (DPPH) radicals by the rad- 
ical scavenging constituents in the digest/extract. The method described by Nanjo et al. (20) was used to investigate the free radical scavenging activity by electron spin resonance (ESR) spectrometer. A $60 \mathrm{mM} \mathrm{DPPH}$ solution in $\mathrm{MeOH}$ was prepared and $60 \mu \mathrm{L}$ of the digest/extract was added to the same volume of freshly prepared DPPH. Then the reactants were thoroughly mixed and transferred to $50 \mu \mathrm{L}$ glass capillary tubes and fitted into the ESR spectrometer. The spin adduct was measured after $2 \mathrm{~min}$. The measurement conditions were as follows; Central field $3475 \mathrm{G}$, modulation width 0.8 $\mathrm{mT}$, amplitude $500 \mathrm{mT}$, microwave power $5 \mathrm{~mW}$, sweep width $10 \mathrm{mT}$.

\section{Superoxide radical scavenging assay}

Superoxide anion radicals generated by UV irradiated riboflavin/EDTA system (21) were detected by an ESR spectrometer using DMPO as a spin trap. The reaction mixture containing $20 \mu \mathrm{L}$ of $0.8 \mathrm{mM}$ riboflavin, $20 \mu \mathrm{L}$ of $1.3 \mathrm{mM}$ EDTA, $20 \mu \mathrm{L}$ of $0.8 \mathrm{mM}$ DMPO and different concentrations of indicated digest/extract. Riboflavin is oxidized to a flavin radicals, with the formation of $\mathrm{O}_{2}{ }^{-{ }^{-}}$in the presence of oxygen (22) via the following reaction: Flavin (red) $+2 \mathrm{O}_{2} \rightarrow$ Flavin (ox) $+\mathrm{O}_{2}{ }^{-{ }^{-}}+2 \mathrm{H}^{+}$. Then, the mixture was irradiated for 1 min under a UV lamp at $365 \mathrm{~nm}$ and transferred to the capillary tube. Spin adduct was recorded by the ESR spectrometer under the following operating conditions; central field 3475 $\mathrm{G}$, modulation $0.1 \mathrm{mT}$, amplitude $200 \mathrm{mT}$, scan width $10 \mathrm{mT}$, microwave power $1 \mathrm{~mW}$, sweep time $30 \mathrm{~s}$.

\section{Hydroxyl radical $(\cdot \mathrm{OH})$ scavenging assay}

The ability of the enzymatic digest/extract to scavenge hydroxyl radicals was investigated by the method described by Rosen and Rauckman (23). The Fenton reaction $\left(\mathrm{Fe}^{2+}+\mathrm{H}_{2} \mathrm{O}_{2} \rightarrow \cdot \mathrm{OH}+\mathrm{OH}^{-}\right)$, a well known and defined generator of $\cdot \mathrm{OH}$ radicals, was used to produce $\cdot \mathrm{OH}$ and the radicals produced were reacted rapidly with nitrone spin trap DMPO. The reaction mixture contained $20 \mu \mathrm{L}$ digest/extract, $20 \mu \mathrm{L}$ of $0.3 \mathrm{M}$ DMPO, $20 \mu \mathrm{L}$ of $10 \mathrm{mM} \mathrm{FeSO}{ }_{4} \cdot 7 \mathrm{H}_{2} \mathrm{O}$ and $20 \mu \mathrm{L}$ of $10 \mathrm{mM} \mathrm{H} \mathrm{H}_{2} \mathrm{O}_{2}$. The resultant DMPO-OH adducts were investigated and the ESR spectrum was recorded after $2.5 \mathrm{~min}$. The measurement conditions were as follows; Central field 3475 $\mathrm{G}$, modulation width $0.2 \mathrm{mT}$, amplitude $100 \mathrm{mT}$, microwave power $1 \mathrm{~mW}$, sweep width $10 \mathrm{mT}$.

\section{Alkyl radical scavenging assay}

Alkyl radicals were generated by AAPH and their scavenging effects were investigated by the method described by Hiramoto et al. (24). The reaction mixture containing $20 \mu \mathrm{L}$ of distilled water, $20 \mu \mathrm{L}$ of the digest/extract, $20 \mu \mathrm{L}$ of $40 \mathrm{mM} \mathrm{AAPH}$ and $20 \mu \mathrm{L}$ of 40
$\mathrm{mM}$ POBN and the mixture was incubated at $37^{\circ} \mathrm{C}$ for $30 \mathrm{~min}$. Then the reactants were transferred to a $50 \mu \mathrm{L}$ glass capillary tube and fitted into the ESR spectrometer. The measurement conditions were as follows; Central field $3475 \mathrm{G}$, modulation width $0.2 \mathrm{mT}$, amplitude 500 $\mathrm{mT}$, microwave power $8 \mathrm{~mW}$, sweep width $10 \mathrm{mT}$.

\section{Hydrogen peroxide scavenging assay}

This assay was carried out according to the method described by Muller (25). The digest/extract $(80 \mu \mathrm{L})$ and $20 \mu \mathrm{L}$ of $10 \mathrm{mM}$ hydrogen peroxide were mixed with $100 \mu \mathrm{L}$ of phosphate buffer $(0.1 \mathrm{M}, \mathrm{pH} 5.0)$ in a 96-microwell plate and incubated at $37^{\circ} \mathrm{C}$ for $5 \mathrm{~min}$. Thereafter, $30 \mu \mathrm{L}$ of freshly prepared $1.25 \mathrm{mM}$ ABTS and $30 \mu \mathrm{L}$ of peroxidase $(1 \mathrm{U} / \mathrm{mL})$ were mixed and incubated at $37^{\circ} \mathrm{C}$ for $10 \mathrm{~min}$ and the absorbance was measured at $405 \mathrm{~nm}$.

\section{Metal chelating ability}

Metal chelating ability was determined according to the method described by Decker and Welch (26) with slight modifications. The digest/extract $(5 \mathrm{~mL})$ was added to a solution of $0.1 \mathrm{~mL}$ of $2 \mathrm{mM} \mathrm{FeCl}_{2}$. The reaction was started by adding of $0.2 \mathrm{~mL}$ of $5 \mathrm{mM}$ ferrozine solution and reaction mixture was incubated for $10 \mathrm{~min}$ at room temperature with shaking. After incubation, the absorbance of reaction mixture was measured at $562 \mathrm{~nm}$.

\section{Lipid peroxidation assay by femic thiocyanate (FTC) method}

The lipid peroxidation inhibitory effect of the digest was determined according to the method described by Osawa and Namiki (27) with slight modifications. Each digest $(2 \mathrm{mg}$ ) was thoroughly mixed with $5 \mathrm{~mL}$ of $2.5 \%$ linoleic acid in ethanol, $5 \mathrm{~mL}$ of $0.05 \mathrm{M}$ phosphate buffer $(\mathrm{pH} 7.0)$ and $2.5 \mathrm{~mL}$ of distilled water. The mixture was kept in the dark at $60^{\circ} \mathrm{C}$ and analyzed every $24 \mathrm{hr}$ intervals. Fifty microlitre of the incubated solution was mixed with $9.7 \mathrm{~mL}$ of $75 \%$ ethanol and $0.1 \mathrm{~mL}$ of $30 \%$ thiocyanate. The mixture was allowed to stand for $5 \mathrm{~min}$ at room temperature before adding $0.1 \mathrm{~mL}$ of $20 \mathrm{mM}$ ferrous chloride in $\mathrm{HCl}$. The absorbance was recorded at $500 \mathrm{~nm}$ with an ELISA reader (Sunrise; Tecan Co., Austria).

\section{Investigation of the reduction of DNA damage (Comet assay)}

Monkey kidney fibroblast cell line (Vero cell) was cultured in DMEM medium containing $10 \%$ fetal bovine serum, streptomycin $(100 \mu \mathrm{g} / \mathrm{mL})$ and penicillin $(100$ unit $/ \mathrm{mL}$ ) at $37^{\circ} \mathrm{C}$ under a humidified atmosphere of $5 \%$ $\mathrm{CO}_{2}$ in air.

Each AMG digest was diluted with PBS to the final 
Table 1. Operating conditions of the FIR drying system and proximate chemical composition of CBPs dried through FIR and FD

\begin{tabular}{lcccccc}
\hline Components & FIR-40 & FIR-50 & FIR-60 & FIR-70 & FIR-80 & FD \\
\hline Dry weight (grams) & 151 & 150 & 149.8 & 148.3 & 147 & 145 \\
Drying time (hrs) & 17 & 13 & 12 & 10 & 6.5 & 48 \\
Heating temperature $\left({ }^{\circ} \mathrm{C}\right)$ & 40 & 50 & 60 & 70 & 80 & -56 \\
Moisture (\%) & $7.31 \pm 0.7$ & $6.77 \pm 0.6$ & $6.76 \pm 0.5$ & $6.3 \pm 0.2$ & $6.3 \pm 0.2$ & $9.17 \pm 0.3$ \\
Ash (\%) & $3.72 \pm 0.05$ & $3.85 \pm 0.06$ & $3.90 \pm 0.07$ & $4.10 \pm 0.08$ & $4.07 \pm 0.07$ & $3.75 \pm 0.07$ \\
Protein (\%) & $9.87 \pm 0.2$ & $9.17 \pm 0.1$ & $9.31 \pm 0.1$ & $9.55 \pm 0.2$ & $9.45 \pm 0.2$ & $9.8 \pm 0.2$ \\
Fat (\%) & $2.1 \pm 0.04$ & $2.2 \pm 0.03$ & $2.1 \pm 0.03$ & $1.5 \pm 0.01$ & $2.6 \pm 0.05$ & $1.6 \pm 0.03$ \\
Carbohydrate (\%) & $77.0 \pm 1.8$ & $78.01 \pm 1.9$ & $77.93 \pm 2.3$ & $78.55 \pm 2.5$ & $77.58 \pm 2.4$ & $75.68 \pm 2.4$ \\
\hline
\end{tabular}

FIR: far infrared radiation-dried CBPs at different temperatures $\left(40 \sim 80^{\circ} \mathrm{C}\right)$, FD: freeze-dried CBPs.

concentration of 25,50 , and $100 \mu \mathrm{g} / \mathrm{mL}$. First, Vero cells $\left(4 \times 10^{4}\right.$ cell $\left./ \mathrm{mL}\right)$ were incubated without the digest for $30 \mathrm{~min}$ at $37^{\circ} \mathrm{C}$ in a dark incubator (I). Second, Vero cells $\left(4 \times 10^{4}\right.$ cell $\left./ \mathrm{mL}\right)$ were incubated without the digest for $30 \mathrm{~min}$ at $37^{\circ} \mathrm{C}$ and oxidatively damaged with 100 $\mu \mathrm{M} \mathrm{H}_{2} \mathrm{O}_{2}$ (final concentration) for $5 \mathrm{~min}$ on ice (II). Third, Vero cells $\left(4 \times 10^{4}\right.$ cell $\left./ \mathrm{mL}\right)$ were incubated with the digest of CBPs dried through FIR for $30 \mathrm{~min}$ at $37^{\circ} \mathrm{C}$ in a dark incubator and then treated with $100 \mu \mathrm{M} \mathrm{H}_{2} \mathrm{O}_{2}$ as a final concentration for $5 \mathrm{~min}$ on ice (III). After each treatment, digests were centrifuged at $1500 \mathrm{rpm}$ for 5 min and washed with PBS.

The alkaline comet assay was conducted according to Singh et al. (28) with slight modification. The cell suspensions made in the previous steps were mixed with $100 \mu \mathrm{L}$ of $0.7 \%$ low melting agarose (LMA), and added to the slides precoated with $1.0 \%$ normal melting agarose. After solidification of the agarose, slides were covered with another $100 \mu \mathrm{L}$ of $0.5 \%$ LMA and then immersed in lysis solution $(2.5 \mathrm{M} \mathrm{NaCl}, 500 \mathrm{mM}$ EDTA, $1 \mathrm{M}$ Tris, and $1 \%$ sodium laurylasarcosine, and $1 \%$ Triton X-100) for $90 \mathrm{~min}$. Later, slides were kept in unwinding buffer for another 20 min for DNA unwinding. The slides were next placed in the electrophoresis tank containing $300 \mathrm{mM} \mathrm{NaOH}$ and $1 \mathrm{mM} \mathrm{Na} \mathrm{N}_{2}$ EDTA ( $\mathrm{pH}$ 13.0) and for electrophoresis of the DNA, an electric current of $25 \mathrm{~V} / 300 \mathrm{~mA}$ was applied for 20 minutes. The slides were washed two times with a neutralizing buffer (0.4 M Tris, $\mathrm{pH} 7.5)$ for $10 \mathrm{~min}$, and treated with ethanol for another $5 \mathrm{~min}$ before staining with $40 \mu \mathrm{L}$ of ethidium bromide $(20 \mu \mathrm{L} / \mathrm{mL})$. Measurements were made by image analysis (Kinetic Imaging, Komet 5.0, UK) and fluorescence microscope (LEICA DMLB, Germany), determining the percentage of fluorescence in the tail (tail intensity, TI; 50 cells from each of two replicate slides).

\section{Statistical analysis}

All experiments were conducted in triplicate $(n=3)$ and an ANOVA test (using SPSS 11.5 statistical software) was used to compare the mean values of each treatment. Significant differences between the means of parameters were determined by using Duncan's test $(\mathrm{p}<0.05)$.

\section{RESULTS AND DISCUSSION}

The operating conditions of the FIR drying system and the proximate chemical composition determined according to the AOAC (29) guidelines are presented in Table 1. The CBPs dried through FIR at the different temperatures were digested by six carbohydrases and Fig. 1 shows the yield of each digest. Both total polyphenolic and flavonoid contents were analyzed by colorimetric assays and are presented in Fig. 2 and 3 respectively. The AMG digest was selected for further experiments.

The radical scavenging capacity was evaluated using 2,2-diphenyl-1-picrylhydrazyl (DPPH) radicals and the results are presented in Table 2. The AMG digest from CBPs dried through FIR at $50^{\circ} \mathrm{C}$ showed significantly $(\mathrm{p}<0.05)$ higher activity $\left(\mathrm{IC}_{50} 0.1 \mathrm{mg} / \mathrm{mL}\right)$ than other digests or water extracts. The mechanism of the reaction between antioxidant compounds and the DPPH radicals depends on the structural conformation of the antioxidants.

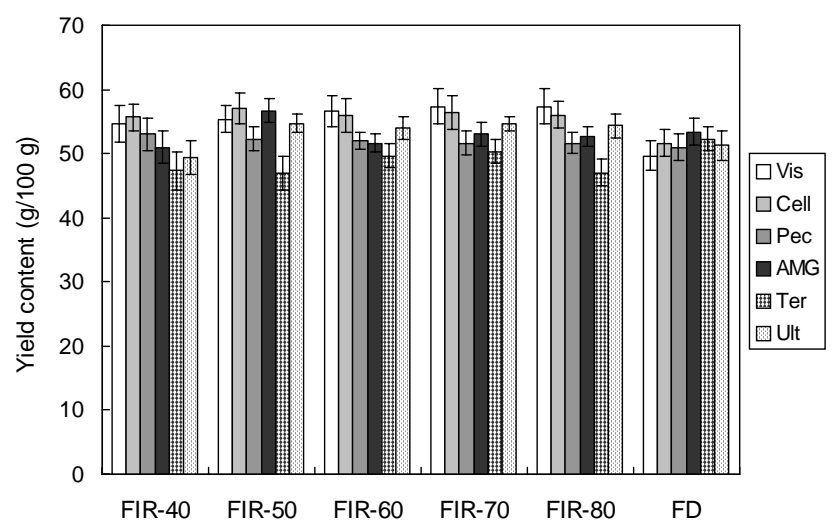

Fig. 1. Yield contents of the enzymatic digests and water extracts from CBPs dried through FIR and FD. Vis: Viscozyme, Cell: Celluclast, Pec: Pectinex, AMG: Aminoglucozydase, Ter: Termamyl, Ult: Ultraflo, WE: water extract. 


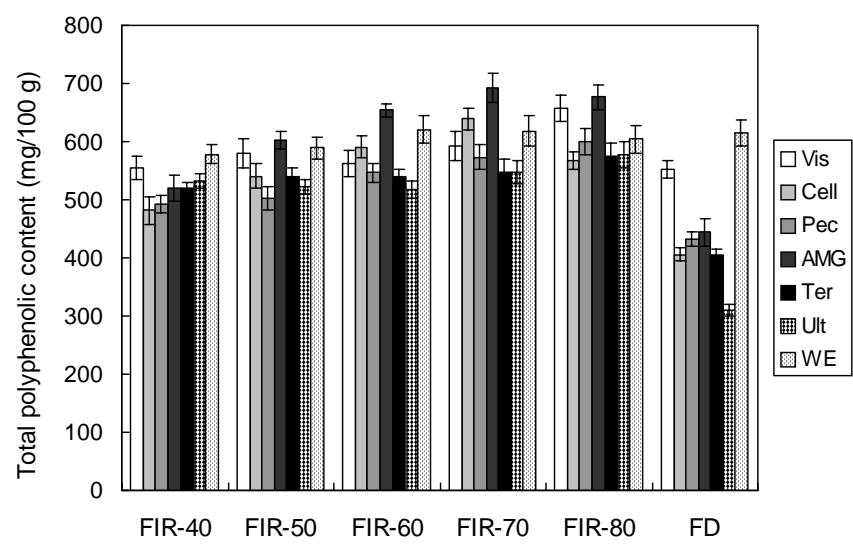

Fig. 2. Total polyphenolic contents of the enzymatic digests and water extracts from CBPs dried through FIR and FD. Vis: Viscozyme, Cell: Celluclast, Pec: Pectinex, AMG: Aminoglucozydase, Ter: Termamyl, Ult: Ultraflo, WE: water extract.

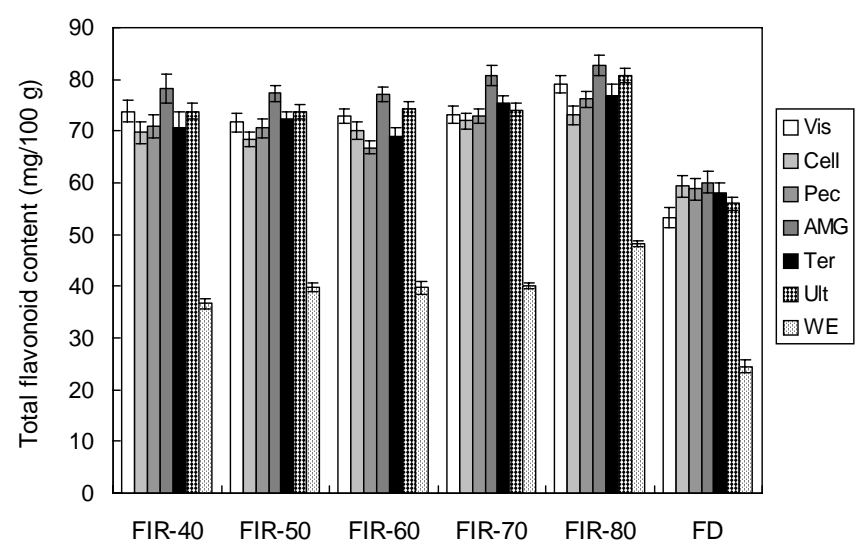

Fig. 3. Total flavonoid content of the enzymatic digests and water extracts from CBPs dried through FIR and FD. Vis: Viscozyme, Cell: Celluclast, Pec: Pectinex, AMG: Aminoglucozydase, Ter: Termamyl, Ult: Ultraflo, WE: water extract.
Some of the compounds react quickly with DPPH radicals reducing a number of DPPH radical equal to the number of the hydroxyl groups (30). Our data were in close agreement with the data reported by Yi et al. (31) with hesperidin, nobiletin and tangeritin, and with one new citrus cultivar. Hence, the activities shown by the enzymatic digest from CBPs may be due to the presence of a variety of polyphenolic and flavonoid compounds.

Superoxide radicals are generated in biological systems during the normal catalytic functions of certain enzymes. As illustrated in the Table 2, all the enzymatic digests and water extracts dose-dependently reduced the ESR signal intensity (ESR spectrum not shown) which indicates their ability to scavenge the superoxide radicals. The superoxide radical scavenging activities of AMG digests from CBPs dried through FIR laid between the $\mathrm{IC}_{50}$ of 0.28 and $0.53 \mathrm{mg} / \mathrm{mL}$ and AMG digest from CBPs dried through FIR at $50^{\circ} \mathrm{C}$ showed significantly higher $(\mathrm{p}<0.05)$ activity $\left(\mathrm{IC}_{50} 0.28 \mathrm{mg} / \mathrm{mL}\right)$ than those of other digests. The superoxide radical scavenging activity of the digests from CBPs dried by FIR at the different temperatures may be due to the presence of polyphenolic compounds and, the increase in the activity is due to increase in number of phenolic hydroxyl groups in the antioxidative molecules. The reports about the superoxide radical scavenging activity of citrus peel or citrus by-products are rare or not available; however, some workers have reported superoxide radical scavenging activities of citrus fruit juice (32).

The AMG digests showed moderate $\mathrm{H}_{2} \mathrm{O}_{2}$ scavenging activities and, in the $\mathrm{H}_{2} \mathrm{O}_{2}$ assay the AMG digest from CBPs dried through FIR at $50^{\circ} \mathrm{C}$ showed significantly

Table 2. Antioxidative effect of AMG digests and water extracts (WE) from CBPs dried through FIR and FD

\begin{tabular}{|c|c|c|c|c|c|c|c|}
\hline \multirow[b]{2}{*}{ Assay } & \multicolumn{7}{|c|}{$\mathrm{IC}_{50}(\mathrm{mg} / \mathrm{mL}, \text { mean } \pm \mathrm{SD}, \mathrm{n}=3)^{1)}$} \\
\hline & $\mathrm{D} / \mathrm{E}^{3)}$ & FIR-40 & FIR-50 & FIR-60 & FIR-70 & FIR-80 & FD \\
\hline \multirow[t]{2}{*}{ DPPH } & AMG & $0.15 \pm 0.006^{\mathrm{b}}$ & $0.10 \pm 0.005^{\mathrm{a}}$ & $0.13 \pm 0.004^{\mathrm{ab}}$ & $0.13 \pm 0.005^{\mathrm{ab}}$ & $0.14 \pm 0.003^{b}$ & $0.24 \pm 0.008^{\mathrm{d}}$ \\
\hline & WE & $0.29 \pm 0.01^{\mathrm{b}}$ & $0.34 \pm 0.02^{\mathrm{c}}$ & $0.40 \pm 0.02^{\mathrm{d}}$ & $0.36 \pm 0.01^{\mathrm{c}}$ & $0.22 \pm 0.01^{\mathrm{a}}$ & $0.42 \pm 0.02^{\mathrm{d}}$ \\
\hline \multirow[t]{2}{*}{$\mathrm{O}_{2}^{\cdot^{-}}$} & AMG & $0.33 \pm 0.01^{\mathrm{b}}$ & $0.28 \pm 0.01^{\mathrm{a}}$ & $0.53 \pm 0.02^{\mathrm{e}}$ & $0.43 \pm 0.02^{\mathrm{d}}$ & $0.37 \pm 0.01^{\mathrm{c}}$ & $0.59 \pm 0.02^{\mathrm{f}}$ \\
\hline & WE & $0.38 \pm 0.01^{\mathrm{c}}$ & $0.33 \pm 0.01^{\mathrm{b}}$ & $0.42 \pm 0.02^{\mathrm{d}}$ & $0.44 \pm 0.02^{\mathrm{d}}$ & $0.28 \pm 0.01^{\mathrm{a}}$ & $0.40 \pm 0.01^{\mathrm{c}}$ \\
\hline \multirow{2}{*}{$\mathrm{H}_{2} \mathrm{O}_{2}$} & AMG & $0.99 \pm 0.05^{\mathrm{b}}$ & $0.65 \pm 0.03^{\mathrm{a}}$ & $0.81 \pm 0.04^{\mathrm{ab}}$ & $0.81 \pm 0.04^{\mathrm{ab}}$ & $0.66 \pm 0.03^{\mathrm{a}}$ & $0.66 \pm 0.02^{\mathrm{a}}$ \\
\hline & WE & $0.99 \pm 0.04^{\mathrm{ab}}$ & $0.62 \pm 0.03^{\mathrm{ab}}$ & $0.82 \pm 0.04^{\mathrm{ab}}$ & $0.82 \pm 0.05^{\mathrm{a}}$ & $0.61 \pm 0.03^{\mathrm{ab}}$ & $0.62 \pm 0.02^{\mathrm{b}}$ \\
\hline \multirow[t]{2}{*}{$\cdot \mathrm{OH}$} & AMG & $0.29 \pm 0.01^{\mathrm{a}}$ & $0.46 \pm 0.03^{\mathrm{ab}}$ & $0.71 \pm 0.05^{\mathrm{c}}$ & $0.66 \pm 0.05^{\mathrm{c}}$ & $0.56 \pm 0.03^{b c}$ & $0.70 \pm 0.04^{\mathrm{c}}$ \\
\hline & WE & $0.81 \pm 0.06^{\mathrm{ab}}$ & $1.04 \pm 0.04^{\mathrm{cd}}$ & $0.88 \pm 0.03^{b c}$ & $1.11 \pm 0.06^{\mathrm{d}}$ & $0.99 \pm 0.05^{\mathrm{bcd}}$ & $0.66 \pm 0.05^{\mathrm{a}}$ \\
\hline \multirow[t]{2}{*}{ Alkyl } & AMG & $0.05 \pm 0.002^{\mathrm{b}}$ & $0.02 \pm 0.001^{\mathrm{a}}$ & $0.06 \pm 0.002^{b}$ & $0.05 \pm 0.002^{\mathrm{b}}$ & $0.04 \pm 0.001^{\mathrm{b}}$ & $0.09 \pm 0.003^{\mathrm{c}}$ \\
\hline & WE & $0.06 \pm 0.002^{\mathrm{a}}$ & $0.05 \pm 0.002^{\mathrm{a}}$ & $0.11 \pm 0.005^{\mathrm{c}}$ & $0.10 \pm 0.004^{b c}$ & $0.09 \pm 0.004^{b}$ & $0.16 \pm 0.005^{\mathrm{d}}$ \\
\hline \multirow[t]{2}{*}{$\mathrm{MC}$} & AMG & $0.41 \pm 0.02^{\mathrm{a}}$ & $0.40 \pm 0.01^{\mathrm{a}}$ & $0.41 \pm 0.02^{\mathrm{a}}$ & $0.83 \pm 0.05^{\mathrm{c}}$ & $0.49 \pm 0.03^{\mathrm{b}}$ & $1.38 \pm 0.07^{\mathrm{d}}$ \\
\hline & WE & $0.80 \pm 0.05^{\mathrm{c}}$ & $0.91 \pm 0.06^{\mathrm{e}}$ & $0.85 \pm 0.06^{\mathrm{d}}$ & $0.74 \pm 0.03^{\mathrm{a}}$ & $0.77 \pm 0.05^{\mathrm{b}}$ & $0.95 \pm 0.06^{\mathrm{f}}$ \\
\hline \multirow[t]{2}{*}{ Yield $^{2)}$} & AMG & 51.0 & 56.7 & 51.7 & 53 & 52.7 & 53.3 \\
\hline & WE & 43.7 & 43.0 & 44.6 & 44 & 46.3 & 43.5 \\
\hline
\end{tabular}

${ }^{1)}$ Values within a row followed by different superscript letters are significant difference $\left(\mathrm{p}^{<0.05) .}{ }^{2)}\right.$ Yield expressed as $\mathrm{g} / 100$ g. ${ }^{3)} \mathrm{D} / \mathrm{E}:$ AMG digest/Water extract. 
higher $(\mathrm{p}<0.05)$ activity (Table 2$)$. We are the first to report hydrogen peroxide scavenging activity of citrus by-products. It has already been proven that dietary polyphenolic compounds protect the cells from cytotoxicity induced by $\mathrm{H}_{2} \mathrm{O}_{2}(33,34)$, indicating that the observed $\mathrm{H}_{2} \mathrm{O}_{2}$ scavenging activity of AMG digests could be due to the presence of phenolic compounds, especially the flavonoid compounds.

Among the oxygen radicals, hydroxyl radicals are the most reactive, and can react with almost all the substances in the cell and induce severe damage to cells (35). Hence, hydroxyl radical scavenging activity was evaluated and the AMG digest from CBPs dried through FIR at $40^{\circ} \mathrm{C}$ showed higher activity than those of other digests $\left(\mathrm{IC}_{50} 0.29 \mathrm{mg} / \mathrm{mL}\right)$. Further, the activity was higher than that of AMG digest from CBPs dried through FD or water extracts (Table 2). The activities exhibited by the digests/extracts could partly be due to metal chelating activity, which retards the generation of hydroxyl radicals via the Fenton reaction, in contrast to the activities exerted by the flavonoids and other polyphenolic compounds present in the enzymatic digests or water extracts which were evaluated by the colorimetric assays. Several studies have reported hydroxyl radical scavenging activities of citrus peel and have also proved that the polyphenolic compounds and flavonoid compounds were responsible for those activities (36).

Further, AMG digests and water extracts were able to reduce the intensities of ESR spectrum of alkyl radicals generated by the APPH (ESR spectrum not shown). The AMG digests showed higher activities than those of water extracts. The inhibitory effect of the digests/extracts on alkyl radicals represents the direct radical scavenging activity. The inconsistency of these digests/extracts on free radical scavenging activity may come from the different inhibitory mechanisms in different model systems. In addition, the AMG digests showed concentration-dependent activity in all the assays tested. Fukumoto and Mazza (37) have reported that increases in the number of hydroxyl groups in the compounds may increase the antioxidative activities. Further, Dziedzic and Hudson (38) have reported that at least two hydroxyl groups were required for antioxidant activities of polyphenolic compounds.

The polyphenolic compounds present in the digests may be able to play a protective role against oxidative damage by sequestering ferrous (II) ions that may otherwise catalyze Fenton-type reactions or participate in metal-catalyzed hydroperoxide decomposition reactions. Table 2 shows the $\mathrm{IC}_{50}$ values of chelating activities of AMG digests and water extracts on ferrous ions. The metal chelating activity of the AMG digests from CBPs dried through FIR was higher than those of its counterparts, the AMG digest from CBPs dried through FD or water extracts. The digest from CBPs dried through FIR at $50^{\circ} \mathrm{C}$ showed the highest metal chelating activity. Hence, these results revealed that enzymatic digests from CBPs has an effective potential for iron binding, suggesting that its action as a protector against peroxidation might be partly related to its iron-binding capacity. Lin et al. (39) have reported the metal chelating activities with green tea and have analyzed catechin contents (flavonoid) in the extracts; however, those activities were lower than the activities reported in this study.

A linoleic acid emulsion system was used in the present study to evaluate the lipid peroxidation inhibitory activity of the digests. Peroxyl (ROO) and alkoxyl (RO) radicals, derived from the lipid peroxide, were employed directly to initiate lipid peroxidation in this model system (40). The $\mathrm{Fe}^{2+}$ ions are oxidized into $\mathrm{Fe}^{3+}$ ions by the peroxides formed during the lipid peroxidation. The $\mathrm{Fe}^{3+}$ ions are capable of forming a complex with $\mathrm{SCN}^{-}$, which has a maximum absorbance at $500 \mathrm{~nm}$ (41). Thus, a high absorbance value was an indication of high peroxide formation during the emulsion incubation. As shown in Fig. 4, the digests from CBPs dried through FIR showed strong lipid peroxidation inhibitory activities. Further, those activities were compared with the results obtained for the commercial antioxidants, BHT and $\alpha$-tocopherols. All digests showed higher activities than that of $\alpha$-tocopherols but lower activities than that of BHT. However, the digests showed strong inhibitory activities against lipid peroxidation compared with control sample (that is without sample treatment). These results indicate that the active components in the

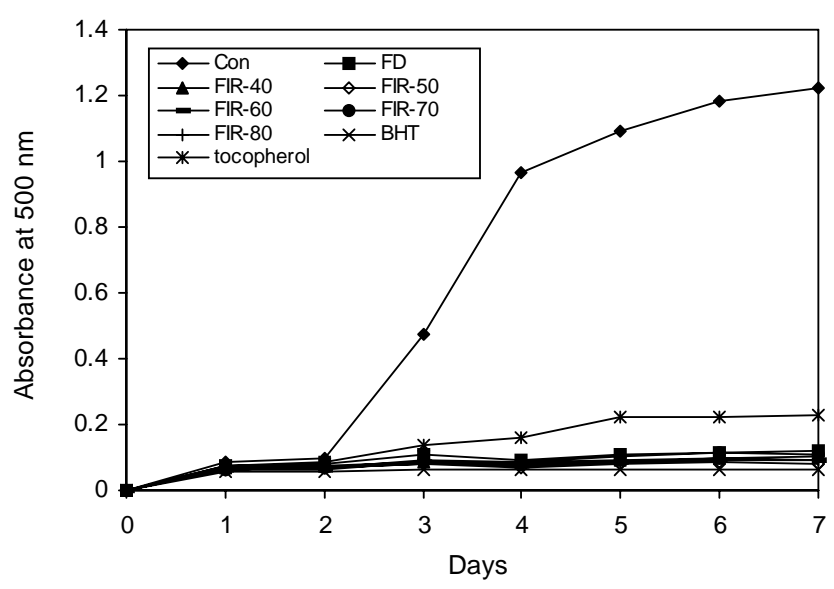

Fig. 4. Lipid peroxidation inhibitory activities of AMG digests from CBPs dried through FIR and FD. The concentration of the digests and positive controls (BHT and $\alpha$-tocopherol) were $2 \mathrm{mg}$. 


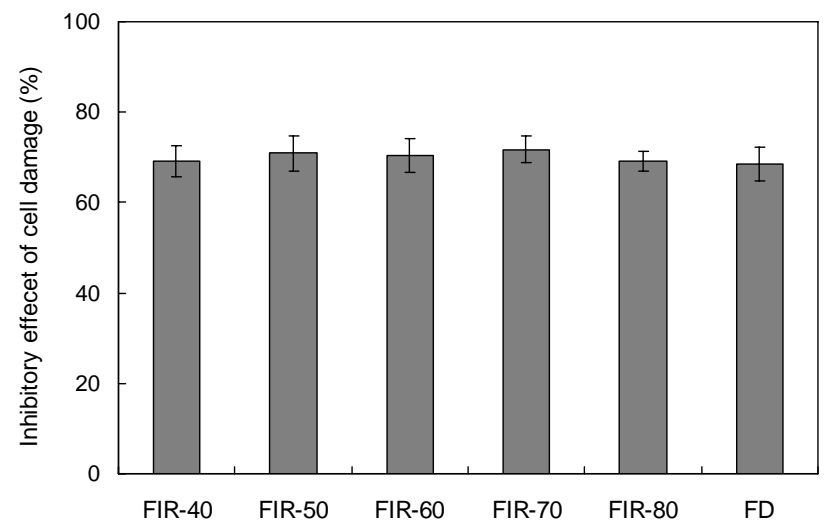

Fig. 5. Effect of AMG digests from CBPs dried through FIR against $\mathrm{H}_{2} \mathrm{O}_{2}$-induced DNA damage in Vero cells. The concentration of the digests was $100 \mu \mathrm{g} / \mathrm{mL}$.

digests, probably the pehnolic compounds including flavonoids, can significantly inhibit the peroxidation of linoleic acid and reduce the formation of hydroperoxide, thus implying that they are potential natural antioxidants. Since it is believed that lipid peroxidation is one of the causes of the occurrence of cardiovascular disease (42) and cancer (43), the inhibition by the digests from CBPs may be an indicator of their high therapeutic potential. Furthermore, it has been reported that flavonoids have the potential to terminate the chain reactions of lipid peroxidation by scavenging the peroxyl radicals (44).

The in vitro alkaline $(\mathrm{pH}>13)$ comet assay is the most frequently used assay for routine screening of potential genotoxic agents (45), and can be performed with a variety of cell types. Vero cells were selected in this study because of their stable karyotype, short generation time, and their easiness to maintain. The alkaline comet assay described by Singh et al. (28) detects primary (repairable) DNA single- and double-strand breaks and alkali-labile sites. DNA damage was induced by $\mathrm{H}_{2} \mathrm{O}_{2}$ in Vero cells. Hydrogen peroxide is able to interact with DNA through highly reactive oxygen and radical species causing severe oxidative damage (46). Exposure of DNA to oxidative stress leads to different types of base damage, producing oxidized and ring-fragmented nitrogenous bases (47). As expected, exposure of Vero cells to $\mathrm{H}_{2} \mathrm{O}_{2}$ resulted in a significant increase in DNA damage. Pre-treatment of the Vero cells with different concentrations (only $100 \mu \mathrm{g} / \mathrm{mL}$ shown in the Fig. 5) of the AMG digests from CBPs dried through FIR significantly inhibited the DNA damage induced by $\mathrm{H}_{2} \mathrm{O}_{2}$. Photomicrographs of Vero cells obtained for AMG digest from CBPs dried through FIR at $50^{\circ} \mathrm{C}$ are shown in Fig. 6. Hydrogen peroxide, a potent genotoxic agent, is able to induce oxidative DNA damage including DNA strand breakage and base modification (48). Furthermore, oxidative DNA damage has been recognized as
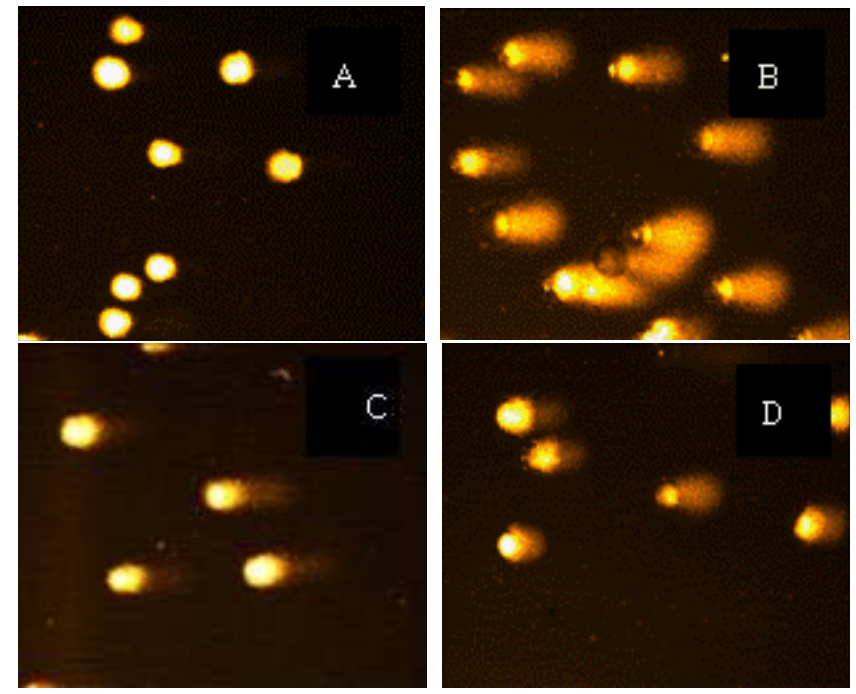

Fig. 6. Photomicrograph of Vero cells obtained for AMG digest from CBPs dried through FIR at $50^{\circ} \mathrm{C}$. (A) negative control, (B) Vero cells treated with $100 \mu \mathrm{M} \mathrm{H}_{2} \mathrm{O}_{2}$, (C) Vero cells treated with $50 \mu \mathrm{g} / \mathrm{mL}$ AMG digest from CBPs dried through FIR at $50^{\circ} \mathrm{C}+100 \mu \mathrm{M} \mathrm{H}_{2} \mathrm{O}_{2}$, (D) Vero cells treated with 100 $\mu \mathrm{g} / \mathrm{mL}$ AMG digest from CBPs dried through FIR at $50^{\circ} \mathrm{C}$ $+100 \mu \mathrm{M} \mathrm{H} \mathrm{H}_{2} \mathrm{O}_{2}$.

a major cause of cell death and mutations in all aerobic organisms. In humans, oxidative DNA damage is also considered an important promoter of cancer (47).

\section{REFERENCES}

1. Huang D, Ou B, Prior RL. 2005 The chemistry behind antioxidant capacity assays. J Agric Food Chem 53: 18411856.

2. Prior RL, Wu X, Schaich K. 2005. Standardized methods for the determination of antioxidant capacity and phenolics in foods and dietary supplements. J Agric Food Chem 53: 4290-4302.

3. Cao G, Sofic E, Prior RL. 1996. Antioxidant capacity of tea and common vegetables. J Agric Food Chem 44: 3426-3431.

4. Wang H, Cao G, Prior RL. 1996. Total antioxidant capacity of fruits. J Agric Food Chem 44: 701-705.

5. Cook NC, Samman S. 1996. Flavonoids-chemistry, metabolism, cardioprotective effects and dietary sources. Nutr Biochem 7: 66-76.

6. Havsteen B. 1983. Biochemical effects of flavonoids. Biochem Pharmacol 32: 1141-1148.

7. Middleton EJ, Kandaswami C. 1994. Potential health promoting properties of citrus flavonoids. Food Technol 18: 115-120.

8. Kim JW, Jeon YJ, Lee JH, Lee SC. 2006. Effect of far-infrared irradiation and heat treatment on the antioxidant activity of extracts from citrus pomaces. J Korean Soc Appl Biol Chem 49: 60-64.

9. Jeong SM, Kim SY, Park HR, Lee SC. 2004. Effect of far-infrared radiation on the activity of extracts from Citrus unshiu peels. J Korean Soc Food Sci Nutr 33: 1580-1583.

10. Jeong SM, Kim SY, Kim DR, Jo SC, Nam KC, Ahn DU, Lee SC. 2004. Effect of heat treatment on the antioxidant 
activity of extracts from citrus peels. J Agric Food Chem 52: 3389-3393.

11. Chawla SP, Jo C, Kang HJ, Kim MJ, Byun MW. 2003. Bioactivities of citrus (Citrus unshui) peel extract subjected to different extraction conditions, storage temperatures and irradiation. J Food Sci Nutr 8: 349-355.

12. Jo C, Lee JW, Byun MW. 2001. Short communication of novel application of food irradiation. J Food Sci Nutr 6: $253-256$.

13. Ginzburg AS. 1969. Application of Infra-red Radiation in Food Processing. Leonard Hill, London. p 353-367.

14. Masamura A, Sado H, Honda T, Shimizu M, Nabethani H, Hakajima M. 1988. Drying of potato by far infrared radiation. Nippon Shokuhin Kogyo Gakkaishi 35: 309-314.

15. Peleg H, Naim M, Rouseff RL, Zehavi U. 1991. Distribution of bound and free phenolic acids in oranges (Citrus sinensis) and grapefruit (Citrus paradise). J Sci Food Agric 57: 417-426.

16. Niwa Y, Miyachi Y. 1986. Antioxidant action of natural health products and Chinese herbs. Inflammation 10: 79-97.

17. Heo SJ, Lee KW, Song CB, Jeon YJ. 2003. Antioxidant activity of enzymatic extracts from brown seaweeds. Algae 18: $71-81$.

18. Chandler SF, Dodds JH. 1993. The effect of phosphate, nitrogen and sucrose on the production of phenolics and solasidine in callus cultures of Solanum laciniatum. Plan Cell Reports 2: 105-110.

19. Zhuang XP, Lu YY, Yang GS. 1992. Extraction and determination of flavonoid in ginkgo. Chinese Herbal Med 23: 122-124.

20. Nanjo F, Goto K, Seto R, Suzuki H, Sakai M, Hara Y. 1996. Scavenging effect of tea catechin and their derivatives on 1,1-diphenyl-2-picrylhydrazyl radical. Free Radical Biol Med 21: 885-902.

21. Guo Q, Zhao B, Shen S, Hou J, Hu J, Xin W. 1999. ESR study on the structure-antioxidant activity relationship of tea catechins and their epimers. Biochem Biophy Acta 1427: 13-23.

22. Hemmerich P, Wessiak A. 1976. The structural chemistry of flavin-dependent oxygen activation. In Proceedings of the fifth international symposium, flavins and flavoproteins. Singer TP, ed. Elsevier, Amsterdam. p 9-22.

23. Rosen GM, Rauckman EJ. 1980. Spin trapping of the primary radical involved in the activation of the carcinogen N-hydroxyl-2-aacetylaminoflurene by cumene hydroperoxide hematin. Mol Pham 17: 233-238.

24. Hiramoto K, Johkoh H, Sako K, Kikugawa K. 1993. DNA breaking activity of the carbon-centered radical generated from 2,2-azobis (2-amidinopropane) hydrochloride (AAPH). Free Rad Res Commun 19: 323-332.

25. Muller HE. 1995. Detection of hydrogen peroxide produced by microorganism on ABTS-peroxidase medium. Zentralbl Bakteriol. Mikrobiol Hyg 259: 151-158.

26. Decker EA, Welch B. 1990. Role of ferritin as a lipid oxidation catalyst in muscle food. J Agric Food Chem 38: 674-677.

27. Osawa T, Namiki M. 1985. Natural antioxidants isolated from eucalyptus leaf waxes. J Agric Food Chem 33: 777-780.

28. Singh NP, McCoy MT, Tice RR, Schneider EL. 1988. A simple technique for quantitation of low levels of DNA damage in individual cells. Exp Cell Res 175: 184-191.

29. AOAC. 1995. Officical Methods of Analysis. 15 ed. Association of Official Anlytical Chemist, Washington, DC.
30. Bondet V, Williams WB, Berset C. 1997. Kinetic and mechanism of antioxidant activity using the DPPH free radical method. Lebensmittel-Wissenschaft Un Technologie 30: 609-615.

31. Yi ZB, Yu Y, Liang YZ, Zeng B. 2008. In vitro antioxidant and antimicrobial activities of the extract of Pericarpium Citri Reticulatae of a new citrus cultivar and its main flavonoids. Food Sci Technol 41: 597-603.

32. Jayaprakasha GK, Patil BS. 2007. In vitro evaluation of the antioxidant activities in fruit extracts from citron and blood orange. Food Chem 101: 410-418.

33. Nakayama T, Yamaden M, Osawa T, Kawakishi S. 1993. Suppression of active oxygen-induced cytotoxicity by flavonoids. Biochem Pharmacol 45: 265-267.

34. Nakayama T. 1994. Suppression of hydroxyperoxide-induced cytotoxicity by polyphenols. Cancer Res 54: 19911993.

35. Dreher D, Junod AF. 1996. Role of oxygen free radical in cancer development. Eur $J$ Cancer 32: 30-35.

36. Anagnostopoulou MA, Kefalas P, Papageorgiou VP, Assimopoulou AN, Boskou D. 2006. Radical scavenging activity of various extracts and fractions of sweet orange peel (Citrus sinensis). Food Chem 94: 19-25.

37. Fukumoto LR, Mazza G. 2000. Assessing antioxidant and prooxidant activities of phenolic compounds. J Agric Food Chem 48: 597-3604.

38. Dziedzic SZ, Hudson BJF. 1983. Hydroxy isoflavones as antioxidants for edible oils. Food Chem 11: 161-166.

39. Lin SD, Liu EH, Mau JL. 2008. Effect of different brewing methods on antioxidant properties on steaming green tea. Food Sci Technol 41: 1616-1623.

40. Cheng Z, Ren J, Li Y, Chang W, Chen Z. 2003. Establishment of a quantitative structure-activity relationship model for evaluating and predicting the protective potentials of phenolic antioxidants on lipid peroxidation. J Pharm Sci 92: 475-484.

41. TakaoT, Kitatani F, Watanabe N, Yagi A, Sakata K. 1994. A simple screening method for antioxidants and isolation of several antioxidants produced by marine bacteria from fish and shellfish. Biotech Biochem 58: 1780-1783.

42. Arts IC, Hollman PC, Feskens EJ. 2001. Catechin intake might explain the inverse relation between tea consumption and ischemic heart disease: The Zutphen Elderly Study. Am J Clinical Nutr 74: 227-232.

43. Takabe W, Niki E, Uchida K, Yamada S, Satoh K, Noguchi N. 2001. Oxidative stress promotes the development of transformation: Involvement of a potent mutagenic lipid peroxidation product acrolein. Carcinogenesis 22: $935-941$.

44. Takahama U. 1983. Redox reactions between kaempferol and illuminated chloroplasts. Plant Physiol 71: 598-601.

45. Collins AR. 2004. The comet assay for DNA damage and repair: principles, applications, and limitations. Mol Biotechnol 26: 249-261.

46. Ratnam DV, Ankola DD, Bhardwaj V, Sahana DK, Kumar MN. 2006. Role of antioxidants in prophylaxis and therapy: a pharmaceutical perspective. J Control Release 113. 189-207.

47. Slupphaug G, Kavil B, Krokan HE. 2003. The interacting pathways for prevention and repair of oxidative DNA damage. Mutat Res-Fund Mol Mech Mutag 531: 231-251.

48. Valko M, Rhodes CJ, Moncol J, Izakovic M, Mazur M. 2006. Free radicals, metals and antioxidants in oxidative stress-induced cancer. Chem Biol Interact 160: 1-40.

(Received October 16, 2008; Accepted October 29, 2008) 